\title{
The Structure of Headlines with Education Theme on Padang Ekspres by Using Van Dijk Model
}

\author{
Eka Rianto, Ermanto, Novia Juita, \\ Universitas Negeri Padang \\ ekarianto1307@gmail.com
}

\begin{abstract}
The purpose of this study was to describe macro-structure, superstructure, and micro-structure in education headlines in Newspaper, Padang Ekspres in 2015, and describe the ideology of education theme in headlines Padang Ekspres in 2015. The study was a qualitative research that uses the descriptive method. The data was collected from education headlines at Padang Ekspres newspaper in 2015. Based on the analysis and session, this study is summarized as follows. First, from 10 news, there are 8 news that discuss about National Exam. Second, preliminary part has the main idea that completely as a introductory news or the introduction of a news. The content part of education headlines has the journalist's opinions, and the point of view from interviewees which has a coherent and united. In the end, the journalist purposely using the implications words, the useful or the benefit of the news, or the statement form interviewees. Third, micro-structure divided into stylistic and syntax. Fourth, on the ideology analysis, the sentence form in Padang Ekspres completely represent for impartiality in $62 \%$ and $38 \%$ for agreement. It can be concluded that the Newspaper Padang Ekspres, as an independent media which is located in West Sumatera especially in Padang City
\end{abstract}

Keywords--News Structure Text, Van Dijk Model

\section{INTRODUCTION}

One of the science developments which is increasingly critical in the middle of society is the problem of journalism. Journalist is someone who searches for news, processes the news, writes news, and composes news that eventually transformed into a profession. Essentially, in news writing of a journalist should meet several provisions, they are: appropriate, direct to the problem, quickly understood, efficient, brief, interesting, and clear in the presentation of the analysis. Therefore, newspaper companies usually hire the language editors whose tasks are processing news and fostering the language of journalists.

Y. B. Setiawan in his research journal entitled The Analysis of Critical Discourse on Gender Based Violence in Suara Merdeka Newspaper (2011. p.18) states that in a sociocultural context, texts that underestimate or marginalize the woman's position representing the patriarchal ideology that exists in society. The way to marginalize a person is determined by the languages used by the journalist to present news.

Other research is also conducted by Imam, A.F (2012, p. 2-4) macro structure refers to the overall meaning (global meaning) that can be observed from the theme or topic rose by a discourse. In other words, macro structure analysis is the analysis of a text combined with the surrounding social conditions to acquire a central theme. The theme of a text is not visible explicitly in the text, but come within the whole text in a coherent form. Therefore, the theme of a text can be found by reading the text wholly as a social discourse so that it can be drawn a central idea or topic or idea developed in the text.

Headlines play an important role in delivering reader's understanding of the content of published news. To understand the news on Padang Ekspres (PE) Newspaper in 2015, especially the headlines, so the Critical Discourse Analysis with Teun A Van Dijk theory is used. According to Van Dijk (in Eriyanto, 2001, p. 225-226), the text dimension consists of three structures. The first is macro structure. Macro structure is the global or general meaning of a text that can be observed by looking at the topic or theme put forward in news. The second is superstructure. The superstructure is the framework of a text consisting of introduction, contents, closing, and schematic conclusions (how part of the sequence of the whole text is imbued), and statistics (how the choice of words used in a text). The third is the micro structure. Micro structure is the discourse meaning that can be observed from the smallest part of a text, that are words, sentences, propositions, clauses, and images.

Next research in the Journal of Indonesian language education and literature, Vol. 2 No. 5 December 2016; Series A 73-81 UNP conducted by Jamaludin A $(2016$, p. 73) research results show The use of thematic text structure by journalists in the discourse of political news of governor election of West Sumatra period 2016-2021 on online media daily portal Singgalang shows no power practice. This imaging balance is realized by journalists through the use of thematic text structures by forming topics put forward in discourse. Topics of discourse formed by journalists are dominating from each pair Candidates of governors, both pair Candidate of Muslim Kasim-Fauzi Bahar and Irwan Prayitno- Nasrul Abit both couples are the best candidates for the future of West Sumatra. Meanwhile, Its shows that the use of thematic text structure by journalists in the discourse of political news The election of West Sumatra governor period 2016-2021 in online media daily portal Singgalang shows the balance of the media to both partners. 
The selection of headline theme of education is based on two things, namely (1) the theme of education is a theme that can reach the interests of society in general and (2) the theme of education is one of the programs that are prioritized by the government. This underlies the importance of studying the structure of the headline text with the theme of education. Furthermore, news of educational themes which made headlines much published in 2015. By 2015, much of the information about the world of education is making headlines. Therefore, Padang Ekspres Newspaper can be used as a source of information to know the problems and education policy.

Based on the above analysis, the researcher is important to conduct a research entitled Text Structure of Headlines Theme of Education in Padang Ekspres Newspaper Year 2015 which is reviewed from the Van Dijk discourse analysis model. In addition, this research will reveal the macro structures, superstructures, and microstructures in the news text at Padang Ekspres Newspaper 2015.

\section{METHODS}

This research type was a qualitative research by using descriptive method. Moleong (2005, p. 6) asserts that qualitative research is a study that intends to understand the phenomenon of what is experienced by research subjects such as behavior, perception, motivation, action, and others. Holistically, it refers to the way descriptions are in the form of words and languages, to a specific, natural context and by utilizing natural methods. Semi (1993, p. 23) states that the descriptive method is a method that is done by describing the data obtained without interpreting the numbers, but prioritizing the depth of appreciation of the interaction between concepts being studied implicitly.

Data in the form of headline theme of education collected as it is obtained in Padang Ekspres Newspaper in 2015. This research will describe the phenomenon naturally without any engineering. The main instrument of this study is the researchers themselves, using a tool in the form of data collection format. The data collection sheet is a sheet containing the analysis of the structure of the text according to Van Dijk.

The research data is the main news with theme of education. The sources of the data research are taken from print mass media. The selected printed media is Padang Ekspres Newspaper in 2015. The main news of education published in 2015 was 10 headlines. The data was collected by researchers by taking newspaper clipping on Padang Ekspres Newspaper in 2015.

Data collection techniques in this study used observation techniques. Observations done is by reading Padang Ekspres Newspaper 2015 with the theme of education. In the process of observation, the researcher uses the technique of referring, furthermore, to inventory the data related to macro structure, superstructure, and micro structure contained in the headline in Padang Ekspres Newspaper 2015.

Data collection methods used in this study is a refer method to the headline theme of education on Padang Ekspres Newspaper in 2015. Furthermore, the techniques used in the refer method are refer, free, involve, and ably techniques (Sudaryanto, 1993, p. 132). Furthermore, to perform data recording, the author uses data inventory format.

Test the validity of the data is done by the technique of persistence observation. According to Moleong (2010, p. 329-330) the persistence technique of observation means seeking consistently interpretations in various ways in relation to a constant or tentative analysis process, seeking an endeavor to limit the range of influences. The validity of the data is done by proof taken directly in the theme news text of education in the Padang Ekspres Newspaper 2015.

This research uses data analysis technique model Miles and Huberman. Miles and Huberman (1992, p. 16) suggested that the activity in qualitative data analysis is done interactively and lasted continuously until complete, so the data saturated. Data saturation sizes are indicated by no new data or information being retrieved.

Activities in the analysis include: data reduction, data presentation, and conclusions. Drawing conclusions is based on the results of data presentation. At this stage the researchers interpret the findings of research tailored to the purpose of research. Based on the qualitative data analysis techniques can be compiled steps analyzing the data of this research as follows: (1) record quotations according to the topics discussed on the basis of the notes, (2) grouping the quotes based on the text structure in the theme headlines education, (3) text structures are grouped according to macro structures, superstructures, and microstructures based on data collection format; (4) Discussion of headlines; and (5) formulate conclusions and suggestions.

\section{FINDING AND DISCUSSION}

In this section, we discuss about three things; the headline macro theme of education at Padang Ekspres Newspaper 2015; the headline superstructure of education theme at Padang Ekspres Newspaper 2015; and the headline microstructure theme of education at Padang Ekspres Newspaper 2015.

\section{1) Macro Structure Marking Headline Ideology of Educational Theme in Padang Ekspres Newspaper 2015}

Based on the analysis conducted, the superstructure that marked the ideology of the main news on the theme of education in the Newspaper Padang Ekspres 2015 seen from thematic structure consists of three categories namely, (1) National Exam, (2) Book, and (3) National Selection of State University Entrance. News in the National Exam category amounted to eight news. News with the category National Selection of State University Entrance amounted to one piece of news and news with the category of Book amounted to one news.

This indicates that education gets a lot of attention from various parties, and deserves to be reported. News about education covers a variety of things, starting from national exam activities, learning resources such as textbooks, and the selection of university entrance activities conducted nationally. Media as a means of disseminating information has a certain influence and power in conveying information to the readers. 
Based on the schematic structure in the headlines of educational themes in the Padang Ekspres Newspaper 2015 it can be seen that news topics have been determined or established first. Following an assessment of the headline structure of the educational theme of the Padang Ekspres Newspaper 2015, the headline theme of education in the Padang Ekspres Newspaper 2015 consists of topic themes and subthemes.

The topic shows the central concept, the most important and dominant thing in a story. In addition, the topic also illustrates the ideas that want to be put forward in viewing and viewing the events being reported. The selection of current and fast-paced topics is one of the things the media must have.

The topic of a story is built by several subthemes. Although some news has the same topic but each news has a different number of subthemes. The use of subtheme in the news shows the point of view in view of an information or news. News is packed by looking at the problems of different aspects embodied in the form of sub-themes so that the reader's interpretation is in line with the media. The whole of the subtheme builds a unity of meaning globally from a news called topic.

The ability of journalists in choosing the topic to be reported is a form of journalist's power over the text of the news to be written. Journalists have full authority over the topics and sub-topics that will be presented in the news. This suggests that in the election of the topic though, the practice of power based on Van Dijk's theory can be found.

\section{2) Super Structure Marking Headline Ideology of theme of Education in Padang Ekspres Newspaper 2015}

According to Van Dijk schematic significance is a journalist's strategy to support a particular topic to be conveyed by arranging parts in a particular order (Eriyanto, 2009, p. 234). The schematic that marks the ideology of the headlines appears from the way journalists put pressure on precedence, and which sections could then be a strategy to hide important information. The concealment effort is done by placing at the end to make it seem less prominent.

The process of preparing a text does not merely involve the technical elements of journalism (which are considered important and worthy given) but have certain effects. Thus, a reflection of the Padang Ekspres ideology can be Ekspresed based on the schematic structure that Padang Ekspres seeks to establish closeness with the reader and organize the reader's mind gradually through the sequence of news delivery.

In the superstructure section, journalists are entitled to choose which important point to report first, it could be the perpetrator, the event, or the scene of an event. In addition, the selection of resource persons also shows the form of power of journalists against the news to be conveyed. The ways journalists sort the news exposure is one form of journalist power in the writing and deliver the news to the readers. Thus, the practice of power in the superstructure based on Van Dijk's theory can be found.

\section{3) Micro Structure Marking Headline Ideology of Educational Theme in Padang Ekspres Newspaper 2015}

The discussion of microstructure is divided into stylistic and semantic. In the stylistic section it usually indicates how a journalist makes word selection over the various possible words that refer to facts. Furthermore, in the syntax section usually describes the coherence, pronouns and sentence forms used by journalists.

Based on the syntactic study used in the headlines of Padang Ekspres, one of the dominant pronouns used in Padang Ekspres media is the singular second person pronoun "dia." The use of the pronoun he indicates the unity or form of the individual which is a form of manipulation that the sentence of the news produced able to form certain implications and objectives. Thus, the use of pronouns in the media of Padang Ekspres shows that there is no alignment.

In Outline the ideology of journalists depicted in Padang Ekspres newspapers in the form of sentences is classified as impartial and does not want to immediately state before the facts are raised. Journalists also do not cover or any particular interest. In essence, journalists are open and there is no doing sidewise or impartial, the reporter explained according to the fact that happened in the field

Picture. 1

The Diagram of Padang Ekspres tendency Toward Education Headlines in 2015

\section{The Diagram of Padang Ekspres Tendency towards Headlines with Education Theme}

$\triangle$ Aktif Berpihak dan Pasif Berpihak

Aktif Tidak Berpihak dan Pasif Tidak Berpihak

Series1;Aktif $\begin{gathered}\text { Series1; Aktif } \\ \text { Bidak } \\ \text { Berpihak dan } \\ \text { Pasif } \\ \text { Berpihak; } \\ \text { Pasif Tidak } \\ \text { Berpihak; } \\ \text { 200;62\% }\end{gathered}$


Based on the diagram above, it can be seen that the data analysis of headlines with educational theme on Padang Ekspres Newspaper in 2015 using Van Dijk model has no partiality. If the percentage is calculated, the sentence that shows alignment amounted to $38 \%$ obtained from the sum of active sentence aligned and passive sentence in favor of headline theme of education in Padang Ekspres Newspaper 2015 which amounted to 125 sentences of the total sentence 325 sentences. Furthermore, the sentence that shows no alignments amounted to $62 \%$. The percentage is derived from the sum of active and impartial sentences and passive sentences are not in favor of the headline theme of education in Padang Ekspres Newspaper 2015 which amounts to 200 sentences of the total sentence total 325 sentences. It means, there is no particular interest (the political element of the media Padang Ekspres). Overall, Padang Ekspres media is an independent media located in West Sumatra, especially Padang City.

From the microstructure of headlines the theme of education in Padang Ekspres Newspaper 2015 can be seen that mark the ideology of journalists to the news. It shows the impartiality of the media on the theme of the education theme of certain elements. Judging from the comparison of the percentage of sentence form, between sentence and nonalignment indicates that there is no particular interest in the news.

The ability of journalists in choosing words, pronouns, hyphens, and the form of sentences used in the news is a form of power of a journalist against the text of the news to be written. Journalists have full power over words, pronouns, hyphens, and sentence forms that will be presented in the news. This suggests that in the micro structure especially the word, pronoun, hyphen, and even sentence form, the practice of power based on Van Dijk's theory can be seen clearly.

\section{CONCLUSION AND RECOMMENDATION}

Based on the data analysis of the main text structure of the theme of education on Padang Ekspres Newspaper 2015 using Van Dijk model can be drawn into the following conclusions.

Macro or thematic structure is a general description of a text or commonly referred to core ideas, summaries, or the most important thing of a text. The theme of education on the headlines of the Padang Ekspres Newspaper 2015 is dominated by National Examination news. Thus, a reflection of the ideology implicit in Padang Ekspres media coverage seems so proactive to education. This proves that the National Examination is a top priority in the preaching of educational themes in the Newspaper Padang Ekspres. It is proven that from 10 pieces of news, there are 8 pieces of news that discuss about National Exam.

On the superstructure is outlined about the headline theme schematic of the educational theme on the Newspaper Padang Ekspres 2015. Each news starts from the introduction, the content / conversation and ending with the cover. Every news has a scheme or groove from the introduction to the end. The introductory section usually contains a news introduction or an introduction to a story. It was deliberately done by journalists because reporters want to convey the main idea as a whole. But the reporters explain the outline in the beginning. In addition, it also aims to provide closeness with the reader.

The microstructure is divided into stylists and syntax. In the stylistic section it usually indicates how a journalist makes word selection over the various possible words that refer to facts. in terms of stylism, a journalist can choose one of several equivalents of words that have the same meaning or meaning based on his ideology on the news he wrote. Of the many choices of words, journalists can choose one of these words based on their ideology of the news that he wrote. A similar attitude can be described in different words depending on the journalist's perspective on a problem.

In the syntax section usually describes the coherence, pronouns and sentence form used by journalists. Sometimes reporters use conditional coherence in order to explain the situation and situation in the parent sentence. This is done by journalists to form a unity or coherence. The use of such coherent hyphenations can describe the ideology of a journalist through his or her writing implicitly.

Based on the conclusion of data analysis of the headline text structure of the theme of education on Padang Ekspres Newspaper 2015 using Van Dijk model, the authors recommend the following suggestions. First, For the researchers themselves, can examine the main text structure of the theme of education on Padang Ekspres Newspaper 2015 using Van Dijk model. Second, For society or linguistic analysts can increase knowledge and understanding of linguistic analysis. Third, students, can add knowledge and insight about lingfuistik learning especially on critical discourse. Fourth, Observers can add appreciation to the understanding of Indonesian linguistics especially in critical discourse. Fifth, For further research is expected to study the text structure analysis of the main news theme of education on Padang Ekspres Newspaper in 2015 using Van Dijk model.

\section{References}

Imam, A. F. (2012). Analisis wacana van dijk pada lirik lagu My Heart Will Go On. Journal of Arabic Learning and Teaching 2 (1) (2012). Universitas Negeri Semarang. ISSN 2252-6269.

Dewi, S. B. dan Maulana, S. (2015). Diskursus cyberbullying florence sihombing (analisis wacana kritis teun a. van dijk tentang florence sihombing di dunia maya). Jurnal Ilmiah Komunikasi |MAKNA 5 (2), Agustus 2014-Januari 201. ISSN : 2087-2461.

Eriyanto. (2009). Analisis wacana pengantar analisis teks media. Yogyakarta: LKiS.

Jamaludi. A. (2015). Pemberitaan peristiwa politik pilgub sumatera barat periode 2016-2021 tinjauan analisis wacana kritis perspektif teun a. Van dijk dalam media online portal harian singgalang. Jurnal Pendidikan Bahasa dan Sastra Indonesia, 2 (5). September 2016; Seri A 73-81.

Moleong, L. J. (2005). Metode penelitian kualitatif. Bandung: Remaja Rosdakarya. 
Miles, M.B \& Huberman, A.M. (1992). Analisis data kualitatif. Terj. Rohendi Rohidi. Jakarta: Universitas Indonesia Press.

Setiawan, Y. B. (2011). Analisis wacana kritis pemberitaan kekerasan berbasis gender di surat kabar harian suara merdeka. Jurnal Ilmiah Komunikasi |MAKNA 2 (1), Februari 2011. 